\title{
Armutveren Köyü’nün (Kırklareli) Kırsal Mimari Özellikleri ve Koruma Önerileri
}

\author{
Soner YELER ${ }^{1}$
}

Öz

Bu çalışmada, kırsal alanlarda insanların yaşanabilir yaşam koşullarının sağlanması ve kırsal yerleşmelerin korunması amacıyla öneriler geliştirilmesi amaçlamaktadır. Kırsal yerleşim alanlarından insanların göç etmesi ile birlikte nüfus giderek azalmaktadır. Bu durum, kırsal alanlarda sosyokültürel ve ekonomik yapının değişmesine neden olduğu gibi kırsal mimarlık özelliklerinin de değişimine yol açmaktadır. Bu kapsamda, kırsal yerleşimlerin sözü edilen değişimlerden en az etkilenmeleri ve özgünlüğünü korumaları amacıyla çalışma alanı olarak seçilen Kırklareli Armutveren Köyü üzerinden öneriler geliştirilmektedir. Çalışmada yöntem olarak literatür çalışması, kırsal yerleşme ve bina mekân analizleri, yerel halk ile yüz yüze sözlü görüşme gibi araştırma tekniklerinden yararlanılmıştır. Yapılan tüm çalışmalardan elde edilen verilerin değerlendirilmesinin, zaman içinde köyün geliştirilmesi üzerine yapılacak çalışmalara temel olacağı düşünülmektedir.

Anahtar Kelimeler: Kırklareli, Armutveren Köyü, Kırsal Mimari, Mimari Kimlik, Koruma.

\section{Rural Architectural Features of Armutveren Village (Kirklareli) and Conservation Suggestions}

\begin{abstract}
In this study, it is aimed to develop suggestions in order to provide livable living conditions for people in rural areas and to protect rural settlements. With the migration of people from rural settlements, the population is gradually decreasing. This situation causes changes in the socio-cultural and economic structure in rural areas as well as changes in the characteristics of rural architecture. In this context, suggestions are developed over Kırklareli Armutveren Village, which was chosen as the study area, in order to ensure that rural settlements are least affected by the changes mentioned and preserve their originality. In the study, research techniques such as literature study, rural settlement and building space analysis, face-to-face interviews with local people were used. It is thought that the evaluation of the data obtained from all the studies will be the basis for the studies to be done on the development of the village over time.
\end{abstract}

Keywords: Kirklareli, Armutveren Village, Rural Architecture, Architectural Identity, Conservation.

\footnotetext{
${ }^{1}$ Kırklareli Üniversitesi, Mimarlık Fakültesi, Mimarlık Bölümü, 39100, Kırklareli

*ilgili yazar/Corresponding author: soner.yeler@klu.edu.tr

Gönderim Tarihi / Received Date: 23.06.2021

Kabul Tarihi / Accepted Date: 26.08.2021
} 


\section{Giriş}

Günümüzde kentlerde, kasabalarda ve kırsal alanlarda daha nitelikli bir çevrenin sağlanması, mevcut yerleşmelerin iyileştirmesi ve yenilenmesi adına neler yapılması gerektiği tartışılmaktadır. Bu tartışmalarda yaşam biçimimizi ortaya koyan sosyoekonomik çevre, kültürel çevre ve doğal çevre önemli konular olmaktadır. Kentsel yerleşmelerde sözü edilen çevre koşulları içinde dengenin yakalanması giderek zorlaşmaktadır. Her ne kadar kırsal alanlarda göçün kente doğru olması, tarımsal ve hayvansal faaliyetlerin azalması, tüketim alışkanlıklarının farklılaşması, doğal çevrenin yıpranması gibi denge bozucu koşullar ortaya çıksa bile, kırsal yerleşmelerde daha kolay ve sağlıklı bir çevre ortamının kurulabileceği düşünülmektedir. Bu kapsamda, kırsal yerleşmeler insanlığın evrimi boyunca var olan, bazı coğrafyalarda kentlerin çekirdeğini oluşturan, doğal ve insani şartların biçimlendirdiği yerleşmeler (Bursa Belediyesi, vd, 2012, s.12) olarak her zaman önemini korumaya devam edeceklerdir.

Yürekli'ye göre; kırsal yerleşmelerde çevre karakterini insan-çevre-kültür ilişkilerinin ışığında, doğal ve kültürel çevre bileşenlerine bağlı olarak açıklamak gerekmektedir. Topografya ve iklime bağlı olup, tarih boyunca arazi kullanılışı ile gelişen çevre karakteri, çevre bileşenlerinin görünen biçim, doku, renk özelliklerinin ve çevreye özgü bir araya geliş şekillerinin ürünü olarak tanımlanmaktadır (Yürekli, 1977). Doğal kaynak kalitelerinin yanında, malzeme, renk, form, cephe düzeni, çatıları ile benzeyen, bulundukları fiziksel çevreye, toplum yapısına göre farklılaşan; kendi kimliğini bulmuş yapılar ve bunların bir araya gelişi yerleşmeye tanınabilir olma özelliği katmakta, kırsal yerleşme karakterini belirlemektedir.

Keleş ve vd. göre; kırsal yerleşmesi iş bölümünün gelişmediği, ekonomisi tarıma dayanan, geniş aile yapısının, yüz yüze komşuluk ilişkilerinin olduğu, bu açıdan kentsel topluluklardan ayrılan toplulukların yaşadığı yerleşmeler olarak tanımlanmaktadır. Bu topluluklar belli bir coğrafya ve ekolojik alanda yerleşmiş, kendine özgü bir işgücü, toplumsal örgütü, kültüre özel bir adı ve geçmişi bulunan, kentten daha az nüfuslu toplum birimleridir (Küçükoğul ve Türkoğlu, 2021, s.48).

Eminağaoğlu'na göre; kırsal yerleşmeler bu bölgede yaşayan insanların ihtiyaçlarına yanıt veren, doğa ile iç içe, arazi formuna uygun, doğal kaynaklara ve etki alanlarına sahip, iklim ile uyumlu, kültürel yapısı, doğal çevresi, konutu ve diğer birimleri ile bir bütün olarak, doğal çevre ve tarihi süreç içerisinde, mimari kültürümüzün oluşumunda önemlidir. Kırsal yerleşmeler günümüzde hala pek çok bölgede yerelliğini koruyabilmiş olarak karşımıza çıkmakta; dönemlerindeki koşullara göre gelişen biçin zenginliği, bölgesel malzeme ve yöresel koşullara uygun rasyonel çözümlü örnekler içermektedir. Kırsal yerleşme karakterini belirleyen unsurlardan biri; doğal kaynak kalitelerinin yanında, malzeme, renk, form, cephe düzeni, çatıları ile benzeyen, bulundukları fiziksel çevreye, toplum yapısına göre farklılaşan; kendi kimliğini bulmuş yapılar ve bunların bir araya gelişi yerleşmeye tanınabilir olma özelliği katmakta, kırsal yerleşme karakterini belirlemektedir (Eminağaoğlu, 2005, s.72-81).

Eminağaoğlu ve Çevik'e göre; kültürel yapısını, ait oldukları dönemin yaşam biçimini mekânlarına yansıtan, halk mimarisinin yaygın görüldüğü çevrelerdir ve günümüzde gittikçe birbirine benzeyen kentlerin tekdüze yapılaşmalarına karşılık; fiziksel çevre ve kendilerine özgü yaşam biçimleri ile şekillenen kırsal yerleşmeler, Anadolu toplumunun kültürel zenginliği içinde bölgeden bölgeye, hatta aynı bölgede, köyden köye farklılık göstermektedir (Eminağaoğlu, Çevik, 2007, s.157-162). 
Kırsal yerleşim karakterindeki köy alanları içerisinde evlerin yoğunlukları göz ardı edilemez. Ancak köy alanlarında köy kahvesi, köy odası, köy mescidi, cami, değirmen ve köprü gibi ortak alanlar olduğu gibi avlu, bahçe, depo ahır, samanlık, kümes, ağıl, ambar ve tuvalet gibi daha özel yapılar da kırsal mimarlığın kapsamına girmektedir (Bursa Belediyesi, vd, 2012, s.6). Bu kapsamda, kırsal mimari kimliğin oluşumunda etkili olan sözü edilen yapıların, farklı çevre koşullarından etkilenerek ne tür bir biçimlenme oluşturduğu ve yerleşmeyi nasıl etkilediğinin anlaşılması için araştırılması ve analiz edilmesi gerekmektedir. Mevcut örnekler üzerinden yapılan çalışmaların; kırsal yaşam kültürünün ortaya konması, kırsal mimarlık mirasının saptanması, belgelenmesi ve korunmasına katkı sağlayacağı açıkça ortadadır.

\section{2. Çalışmanın Yöntemi}

Kırsal yerleşmelerde, kırsal mimari gibi nitelikli konuları bir araya getirerek, kırsal değerlerin korunabilmesi için Kırsal tasarım rehberleri oluşturulmaya başlanılmıştır. Çevre ve Şehircilik Bakanlığının "Kırsal Alanda Yöresel Doku ve Mimari Özelliklerin Belirlenmesi ve Yaygınlaştırılması" adlı proje, Kayseri ili için hazırlanan bir rehber olarak ilk olma özelliği taşımaktadır (Çorapçıoğlu, vd., 2008, s.1). Rehberin ana amacı, kırsal yerleşmelerde yöreye özgü kimliğin bozulmadan, doğru planlama kararları ile kırsal alanın gelişimini sağlayarak mimari değerlerin korunmasıdır.

Sözü edilen rehberde, incelenecek alanlar için mimari kimliğin ortaya konulması ve araştırmanın yapılması için üç başlığa yer verilmiştir. Bunlar: "1. Doğal ve çevresel veriler", "2. Mimari öğeler" ve "3. Kırsal mimari kimliği oluşturan konut ve yerleşim tipleri"dir (Çorapçıŏlu, vd., 2008, s.3)

Çalışma kapsamında seçilen Kırklareli Demirköy İlçesine bağlı Armutveren Köyünün mimari açıdan analiz edilmesinde bu çalışma esas alınmıştır. Çalışmada yer verilen "Kırsal Mimari Analiz" başlığı; "Kırsal Mimariyi Biçimlendiren Özellikler (Doğal Çevre Veriler, Sosyo-Kültüterl Veriler)" ve " Kırsal Mimari Kimliği Oluşturan Yerleşim ve Yapı Özellikleri (Kırsal Yerleşim Özellikleri, Kırsal Yapı Özellikleri)" olarak 2 grupta incelenmiştir. Analiz çalışmaları, öncesinde yapılan literatür taraması ve yerel halk ile yapılan yüz yüze görüşmeler ile desteklenmiştir.

\section{Demirköy İlçesi Armutveren Köyü Kırsal Mimari Analizi}

\subsection{Konumu}

Demirköy, Marmara Bölgesi'nin Trakya kesiminde Kırklareli iline bağlı bir sınır ilçesidir. Yüzölçümü 945 kilometrekare, rakımı 300 metre olan ilçe kuzeyde Bulgaristan, doğuda Karadeniz, güneyde Vize, güneybatıda Pınarhisar ilçeleri, batıda da Merkez ilçeyle çevrilidir. Demirköy, Kırklareli il merkezinden 72 km., Karadeniz sahilindeki İğneada limanından $25 \mathrm{~km}$., İstanbul'dan $224 \mathrm{~km}$. ve Bulgaristan sınırından yaklaşık $50 \mathrm{~km}$. uzaklıktadır. İlçe Merkezi, Yıldız Dağlarının Kuzeydoğu etekleri üzerinde Bulanık Deresi ve onun bir kolu olan Değirmendere tarafından derince yarılmış olan 300 metre yüksekliğinde bir seki üzerinde kurulmuştur. Arazisinin yüzde 91,2 si dağlık olan Demirköy, ayrıca yüzde 8,5 dalgalı araziye ve yüzde 0,3 ova arazisine sahiptir. Fay ve çöküntü alanları göstermeyen Demirköy'ün topoğrafik yapısında 231 hektarlık ova alanının taban suyunun ortaya çıkması ile "Longos Ormanı" denilen bölge meydana gelmiştir.

İlçe topraklarının büyük bölümü dağlık ve ormanlıktır. İlçenin yüzde 67'si ormanlarla kaplıdır. Karadeniz'e koşut bir set oluşturan Istranca (Yıldız) Dağları, güney ve batı 
kesimlerini boydan boya engebeliktir. En yüksek noktası olan Mahya Dağı (1031 m), Demirköy ilçesinin Merkez ilçe ve Pınarhisar ilçesine komşu olduğu kesimde yer alır. Istranca dağlarının yoğun bir orman örtüsü ile kaplı kuzeydoğu yamaçları bol yağış aldığından su kaynakları açısından da zengindir. Deringeçit ve Rezve dereleri ile Bulanıkdere bu akarsuların başlıcalarıdır. Rezve Deresi ilçenin Bulgaristan’la doğal sınırını oluşturur (Canbaz, 2007, s.6).

2020 genel nüfus verilerine göre Demirköy'ün nüfusu 8829'dir. Bu nüfusun 3400'i ilçe merkezinde, 2437'i İğneada Beldesinde ve 2992'si köylerde yaşamakta olup, Demirköy'de toplam 15 köy bulunmaktadır.

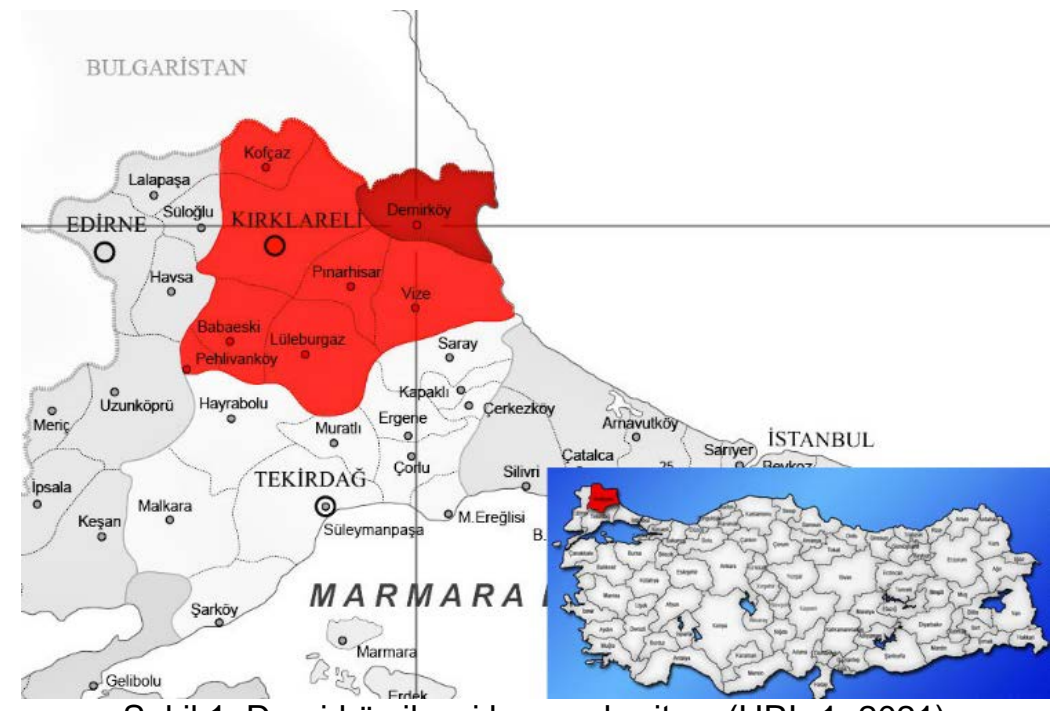

Şekil 1: Demirköy ilçesi konum haritası (URL-1, 2021)

\subsection{Tarihsel Gelişimi}

Demirköy ilçesinin kim tarafından ve hangi tarihte kurulduğu kesin olarak bilinmemekte, MÖ 4200-4000 yılları arasında Trak kabileleri tarafından yerleşim alanı olarak seçildiği sanılmaktadır. İğneada ve Ayastofanos (Beğendik) köylerinin Demirköy'den daha eski yerleşim yerleri olduğu ileri sürülmektedir (Kırklareli Belediyesi, 1967,1972,1990, s.33). Bu yörede, iÖ 1200'lerde Traklar'ın yerleştiği, bugün Kırklareli il sınırları içinde bulunan ve antik devirde Bizye olarak bilinen Vize ilçesinin, Trak kabilelerinden Astlar'ın başkenti olduğu bilinmektedir (Canbaz, 2007, s.10). 1369 yılından önce Bizans hakimiyetinde olan Demirköy bölgesi, Sultan I. Murat Hüdavendigar zamanında Osmanlı topraklarına katılmıştır. Yörenin Osmanlılara geçişi ise 1361'e rastlar. Osmanlı yönetiminde 16. yüzyılda Hanzade Sultan'a temlik edilmiş olan Aya Tudor köyü ve civarındaki madenlerin sınıındaki madenin "bilahara hass-ı humayuna ilhak olunmuş bulunduğu" belirtilmektedir (Kırklareli Belediyesi, 1967). Sözü edilen yer, küçük madenci yerleşmeleri olan bu bölge olmalıdır. Demirköy, bu dönemde önceleri Paşa Livası'na bağlı bir kaza merkezi iken, XVIII yüzyılda sancak olmuştur. XIX yüzyılda Edirne Eyalati'ne bağlı bir sancak merkezi iken 1854'te kaza durumuna geçirilmiş ve 1879'da yeniden sancak olmuştur. 1877 Osmanlı-Rus Savaşı sonunda imzalanan Ayastefanos Antlaşmasıyla, yöre Bulgaristan prensliğine bırakılmış, 1878 Berlin Antlaşmasıyla Osmanlı Devletine geri verilmiştir (Kırklareli Belediyesi, 1967). Bu yöre, Balkan Savaşında Bulgar işgaline uğramıştır. Demirköy, Osmanlı döneminde Kırkkilise'ye (Kırklareli) bağlı bir nahiye merkeziyken, 1908'de kaza yapılmış, Birinci Dünya Savaşı sonlarında, 27 Temmuz 1920'de Yunan işgaline uğrayan kasaba 2 Kasım 1922'de işgalden kurtulmuştur. 
Demirköy Belediyesi 1923'te kurulmuştur. Cumhuriyet dönemi öncesinde Osmanlıca Samakocuk, Bulgarca Малък Самоков (Malık Samokov = Küçük Samakov) olarak adlandırılmıştır. Samako ya da Samakov, su gücüyle çalışan büyük mekanik çekiç anlamına gelen, Slavca'da "samo" ve "kov" sözcüklerinden oluşan bir bileşik isimdir ve "kendidöver" anlamına gelmektedir. Arşivlerde yapılan araştırmalardan elde edilen belgelerde "Samakocuk" isminin "Samakofçuk" ve "Samakovcuk" biçimlerinde kullanıldığı da görülmektedir. Birbirine çok yakın olan bu isimlerin yabancı bir sözcüğün Osmanlıca ve Türkçe'ye farklı yazımlarla aktarıldığı görülmektedir. Daha fazla tercih edilen kullanımının "Samakocuk" olduğu, arşivlerde yapılan araştırmalardan ve bu isimle elde edilen bol miktardaki belgeden anlaşılmaktadır. Bu ad, 20. yüzyılda geçmişteki demir cevheri üretim etkinliğinden ötürü Demirköy şekline dönüşmüştür (Canbaz, 2007, s.12).

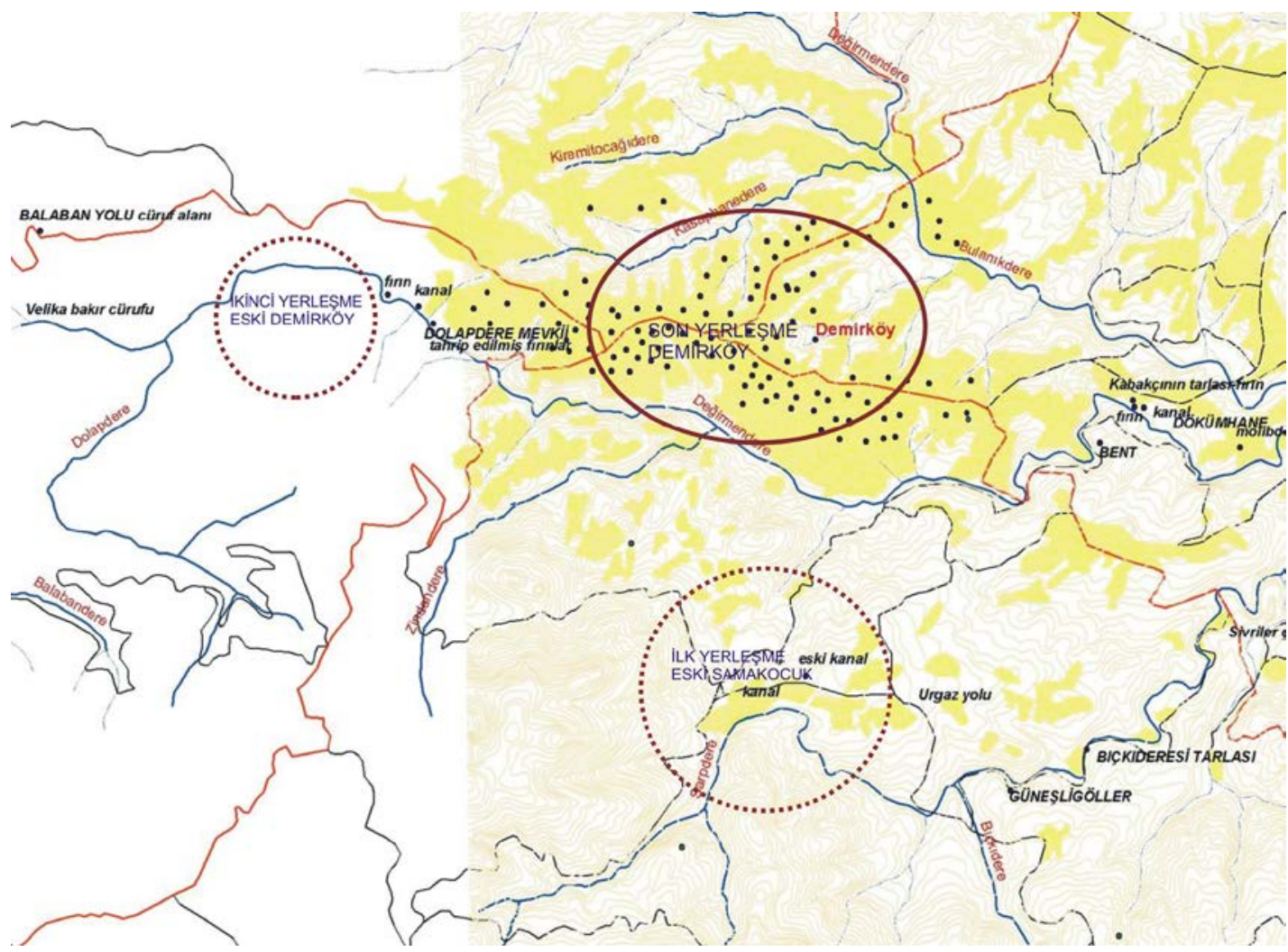

Şekil 2: Demirköy'ün yerleşim sürecini gösteren haritası (G. Tanyeli'den)(Canbaz, 2007, s.12)

\subsection{Sosyo-Ekonomik Yapı}

Toplum bütünlüğünü oluşturan gerek maddi, gerekse manevi unsurların kendine özgü biçimlenişi o bütünlüğün sosyal yapısını ortaya koymaktadır. Bu sonuçtan yola çıkıldığında, toplumu oluşturan bireylerin tapu tahrir defterlerinden, bölgeyi gezen seyyahların verdiği bilgilerden ve Cumhuriyetten sonra yapılan nüfus sayımlarından faydalanarak, geçmişten günümüze nasıl bir değişim geçirdiğini anlamak ve dolayısıyla Demirköy'ün sosyal yapısının hangi evrelerden geçerek bugünkü şeklini aldığını anlamak mümkün olacaktır.

İlçeye, Merkez ve İğneada beldeleri ile 15 köy bağlıdır. Ortalama köy nüfusu 741 kişi olup, ilçede nüfusu 1000'in üzerinde bir tek köy vardır. İlçeye bağlı olan 16 köyün; 2'si ova, 8'i sırt, 1'i vadi, 4'ü yamaç,1'i eteklerde yer alıp hepsi orman içindedir (Canbaz, 2007, s.14). 


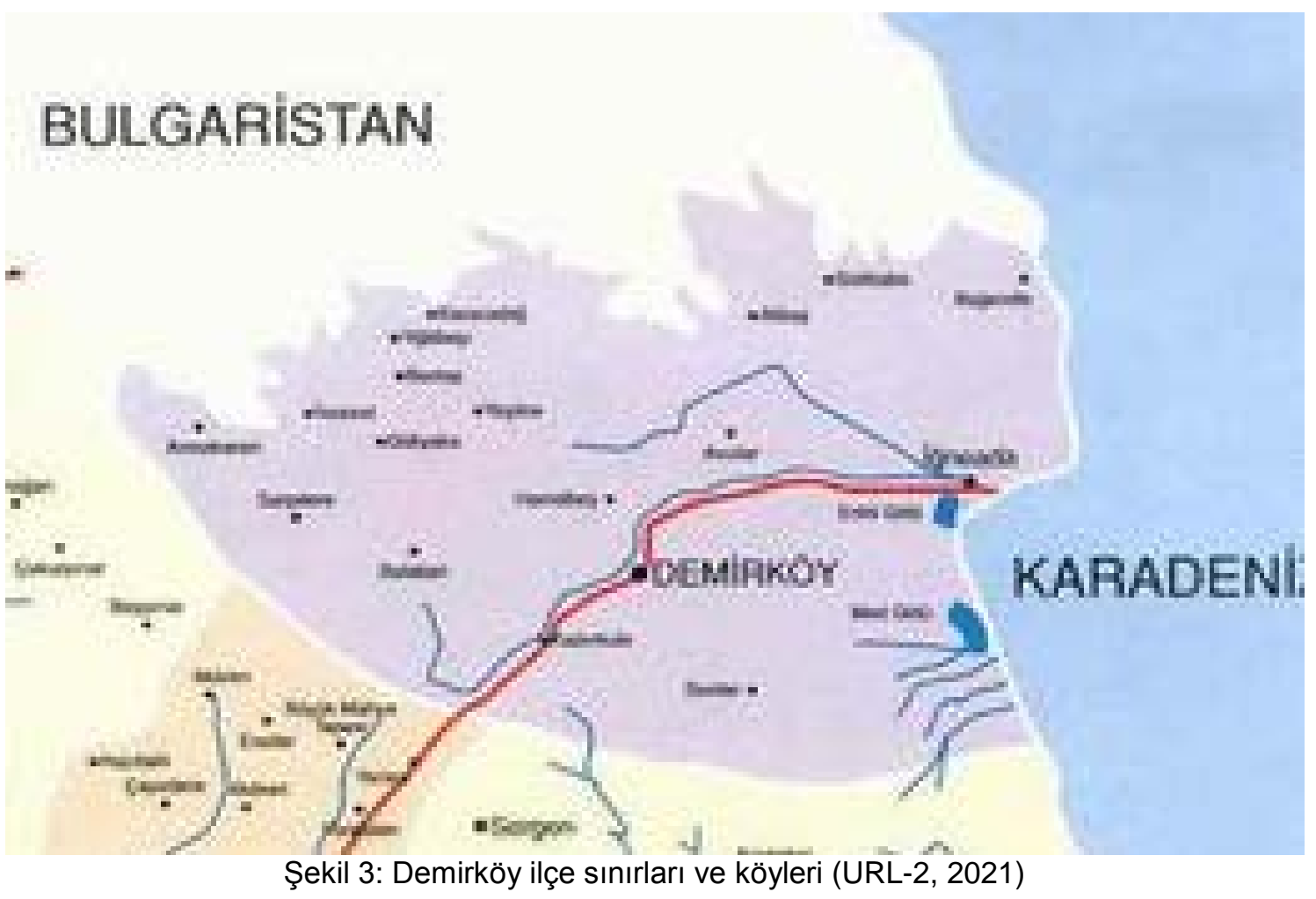

İlçenin Merkez ve İğneada Beldelerine bağlı köyleri şu şekildedir: Demirköy'ün Merkez'e bağlı köyleri; Armutveren (Paspala), Balaban (Velika), Boztaş (Kireçnova), Gökyaka (Mağlevit), Hamdibey (Turulya), İncesırt, Karacadağ, Sarpdere, Sivriler, Yeşilce (Mihalangoz), Yiğitbaşı (Kamilya), İğneada'ya bağlı köyleri; Avcılar (Korfa), Beğendik (Ayastafanos), Limanköy, Sislioba (Pilaça)'dır (Kırklareli Belediyesi, 1967).

İlçenin toprakları nitelikli orman ve baltalıklarla kaplıdır. Ekim alanları hayli sınırlı olan bu kıraç topraklarda genellikle kuru tarım yapılmaktadır. Ekili alanlar, ilçe topraklarının yüzde 10'undan azdır. Patates, buğday, fasulye ve elma ile kereste en önemli ürünlerdir (Kırklareli Belediyesi, 1967).

Demirköy ormanlarında bol miktarda domuz ve kurt bulunmaktadır. Muhtelif avcı dernekleri kış aylarında bu bölgelerde sürekli av partileri düzenlemektedir. İlçenin bataklık, sazlık, deniz ve nehir kenarlarında geçici olmak üzere ördek, kaz ve çulluk avcılığı yapılmaktadır. Demirköy ormanlarında, karaca ve geyik de bulunmaktadır. Ayrıca orman bölgesinde ve ovalarda bol miktarda tavşan ve tilki ile dere kenarlarında porsuk ve soğuk sularda alabalık mevcuttur. Demirköy'ün Velika Deresi alabalık avcılarının devamlı uğrak yeridir (Kırklareli Belediyesi, 1990).

Demirköye'e bağlı, yukarıda isimleri verilen, toplam 15 adet köy bulunmaktadır. Çalışma kapsamında Armutveren (Paspala) Köyü, Bulgaristan sınırına yakın ve Longos Ormanları sınırların içerisinde batı bölgesindeki ilk köy olması, Merkez ilçe ve Demirköy ilçesinin kesişiminde yer yer alması ve bölge tarihinde, Korkut'un (Korkut, 1960, s.27) bilgilerine göre,1960 yılında en büyük nüfusa sahip olması yönleriyle seçilmiş, bu köyün kırsal mimarlık açısından değişimlerinin analiz edilmesinin bölge hakkında da pek çok bilgiyi ortaya koyacağı düşünülmüştür. 


\section{Armutveren Köyü}

Armutveren Köyü, 41 derece 54 dakika kuzey enlemi ve 27 derece 32 dakika doğu boylamında yer almaktadır. Demirköy ilçe merkezinin kuzeybatısında kalan köy yerleşim alanına, Merkez köylerinden Yörükbayır-Çukurpınar köy yolu üzerinden (10 $\mathrm{km}$ sonra) ulaşım sağlanmaktadır. Köy, güneyinde bulunan Kırklareli Merkeze 42 kilometre, kuzeyinde yer alan Bulgaristan sınırına yaklaşık 1-1,2 kilometre, yine kuzeybatısında yer alan Şükrüpaşa Köyüne 8 kilometre, güneydoğusunda yer alan Sarpdere Köyüne 9 kilometre, doğusunda yer alan Karanlık Mahallesi ve İncesırt Köyüne 5-7 kilometre mesafede yer almaktadır.

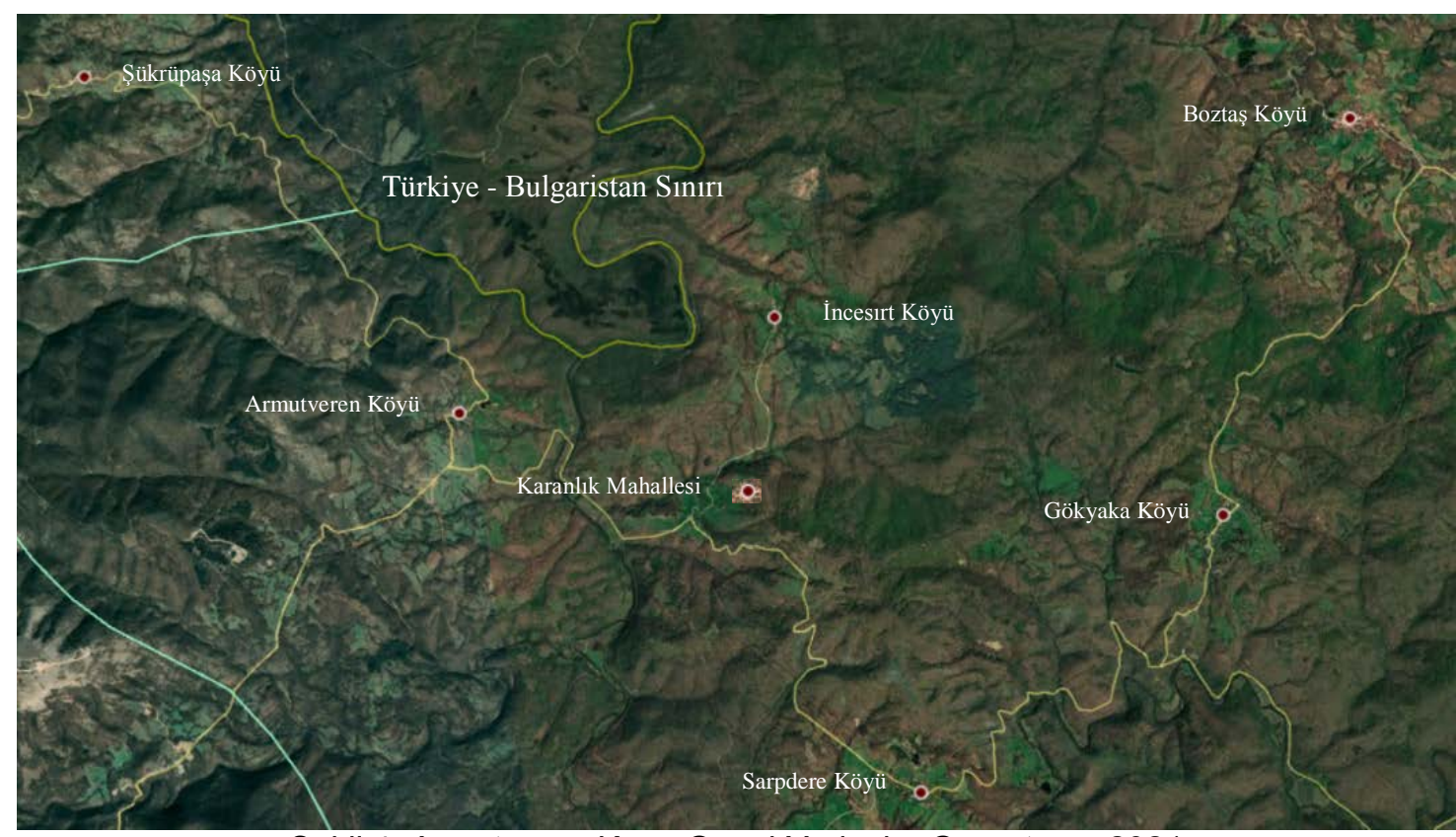

Şekil 4. Armutveren Köyü Genel Yerleşim Görüntüsü, 2021

\subsection{Kırsal Mimariyi Biçimlendiren Özellikler \\ 4.1.1 Doğal Çevre Verileri}

Köy, ortalama $375 \mathrm{~m}$ eş yükselti eğrileri etrafında yer alan bir bölgede kurulmuştur. Köyün kuzeyine doğru gidildikçe yükselti artmaktadır. Köyün kuzeyinde ve batısında ormanlar yer almaktadır. Sınıra çok yakın olduğu için sınırı belirleyen Mutludere, köyün kuzeyinde yer almaktadır. Köyün diğer alanları ise tarlalarla çevrilidir. Köy, adını köyde yetişen iri armutlardan almıştır. Dolayısıyla meyve bahçeleri yerel halkın geçim kaynağını oluştururken köyün de doğal unsuru olmuştur.

\subsubsection{Sosyo-Kültürel Veriler}

Armutveren Köyü, Yunanistan, Drama'dan 1912'lerde gelen göçmenlerin iskân ettiği bir köydür. Balkan Savaşı'yla eski yerlerine geri dönen köylüler, 1925-1928'lerde tekrar köye gelmişlerdir [29]. Köy halkının neredeyse tamamı eski Balkan göçmeni Pomaklar'dan oluşmaktadır. Köyün eski adı Paspala'dır. Özdoğan'ın (2016, s.42-43) köy adlarını araştırdığı tezinde, köylülerle bir sohbet esnasında köyün isminin konulduğu ve bir subayın da bu ismi uygun gördüğü dile getirilmektedir. Kaynakta, köyün yeni adını (Armutveren), köyde yetişen iri armutlardan aldığı belirtilmektedir. Köy, yeni ad almasına rağmen köy halkı ve civar köyler tarafından hala eski adıyla anılmaktadır (URL-3, 2021). 
Armutveren Köyü yerleşimi, Korkut'a (1960, s.43) göre, 1960 yılında 511 kişiden oluşuyormuş. Ancak ilerleyen yıllarda hızlı nüfus azalması köyün zayıflamasına neden olmuştur. Son 30 yılda, çok bir nüfus artışı olmazken 2014 yılında önemli bir artış görülmüştür. Erkek nüfus kadınlara oranla biraz fazladır. 2020 yılında yapılan nüfus sayımında, köyün 30-35 hane olarak yaklaşık 112 nüfustan oluştuğu tespit edilmiştir (URL-4, 2021).

Tarım, hayvancılık ve orman işçiliği köyün geçim kaynaklarındandır. Özellikle burada yetiştirilen ve köyün eski adını alan "paspala fasulyesi" özel değerlerden birisidir (Korkut, 1960, s.43).

\subsection{Kırsal Mimari Kimliği Oluşturan Yerleşim ve Yapı Özellikleri 4.2.1. Kırsal Yerleşim Özellikleri}

Yapılan alan çalışmalarında, Armutveren Köyünün toplu ve düzenli bir yerleşme olduğu görülmüştür. Ancak, köyün belirginleşmiş bir meydanı bulunmamaktadır. Konutların çoğu köy camisinin, okul ve kahvehanelerin çevresinde yer almaktadır. Özellikle cami, okul, dükkân, kahveler, sağlık ocağı gibi işlevli yapılar birbirine yakın olarak aynı çevrede düzenlenmişlerdir.

\section{a. Yollar ve Sınırlar}

Yerleşimde, köy meydanından çıkan üç ana yol ile, kuzeydoğu yönünden Şükrüpaşa Köyüne, güneydoğu yönünde Sarpdere Köyüne ve güney yönünden ise Çukurpınar köyüne ulaşılabilmektedir. Bu köyde yerleşim alanı kuzeyde ormanlar, batıda orman ve tarlalar, doğuda tarlalar ile sınırlanırken, güneyde ise büyük bir tarla alanı ve ana yol tarafından sınırlanmaktadır. Köy meydanı ve yakın çevresinde yollar parke kilit taşı kapladır. Ancak diğer köy yolları toprak malzemelidir. Diğer köylere olan bağlantı yolları asfalt malzeme ile kaplıdır. Yerleşimde, bahçe ve yapı duvarları ve tel sınırları, yerleşimin en belirleyici yapay sınırlarıdır. Bazı konutların avlu duvarı yok iken bazılarında ise alçak taş duvar görülmektedir.

\section{b. Parsel - Yapı - Yol İlişkileri}

Köy içerisinde farklı boyutlarda parseller bulunmaktadır. Kırsal yerleşimin karakteri; parsellerin arazi üzerindeki biçimlenişi, yapıların parsele konumlanış özellikleri ve bu özelliklerin yol ile ilişkilerinden oluşmaktadır. Genel olarak, yol ile yapı ilişkisinde komşu parsel ile de ilişkili kurulabildiği gibi, tamamen parsel içerinde merkezi bir konumlandırma da söz konusudur. Hatta kırsal yerleşim karakteri gereği, parsele intiyaç doğrultusunda yapı yapma özelliğini de görmek mümkündür.

\section{c. Ortak Mekân Kullanımları}

Armutveren Köyü halkından alınan bilgiler ve yapılan gözlemler sonucunda; erkeklerin cami, kahvehanelerde, kadınların ise bina bahçe ve ev önlerinde zaman geçirdiği görülmüştür. Özel günlerde (düğün ve etkinler), binaların önündeki yolların ve binaların bahçelerinin kullanımı söz konusudur. Bazı etkinliklerde boş olan sağlık ocağı da kullanılabilmektedir. Köy içinde çocuk sayısı az olduğundan, çocuklar için özelleşmiş mekânlar yoktur. Çocuklar, daha çok sokaklarda, bina bahçelerinde ve ev önlerinde zaman geçirmektedir. 

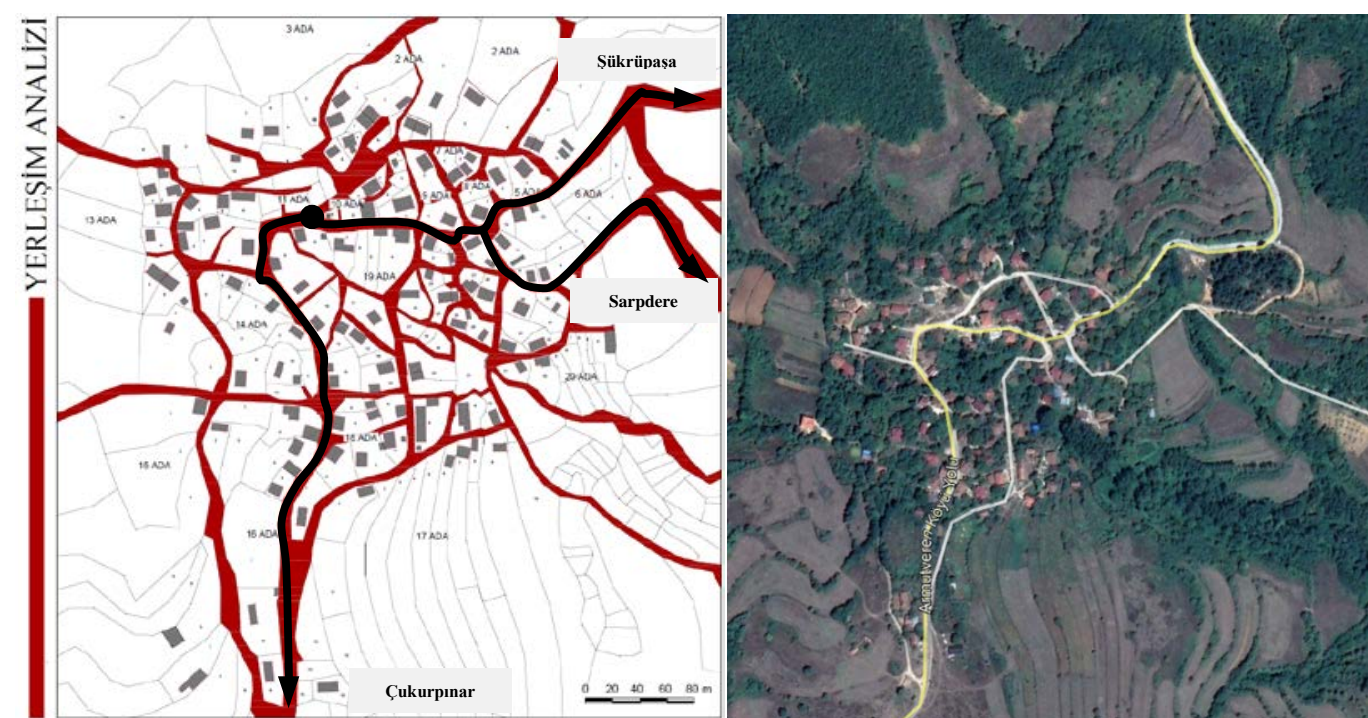

Şekil 5. Armutveren Köyü Genel Yerleşim Analiz Paftası ve Görüntüsü, (Soner Yeler Arşivinden, 2018)

\subsubsection{Kırsal yapı özellikleri}

\section{a. İşlev Analizi}

Armutveren Köyü yerleşiminde 137 adet yapı tespit edilmiştir. Yerleşim alanında okul, cami ve sağlık ocağı 1'er adet, ayrıca 2 adet kahvehane ve bunların birisinin içerisinde muhtarılık bulunmaktadır. Sözü edilen yapıların tüm yapıların içerisindeki oranı \%1'dir. Yerleşim alanında en yoğun işlev, 55 adet ile konut+ahır (\%40) işlevidir. Ayrıca 23 adet depo/ambar (\%16), 22 adet konut (\%16) ve 20 adet ahır (\%15) işlevleri de mevcuttur.
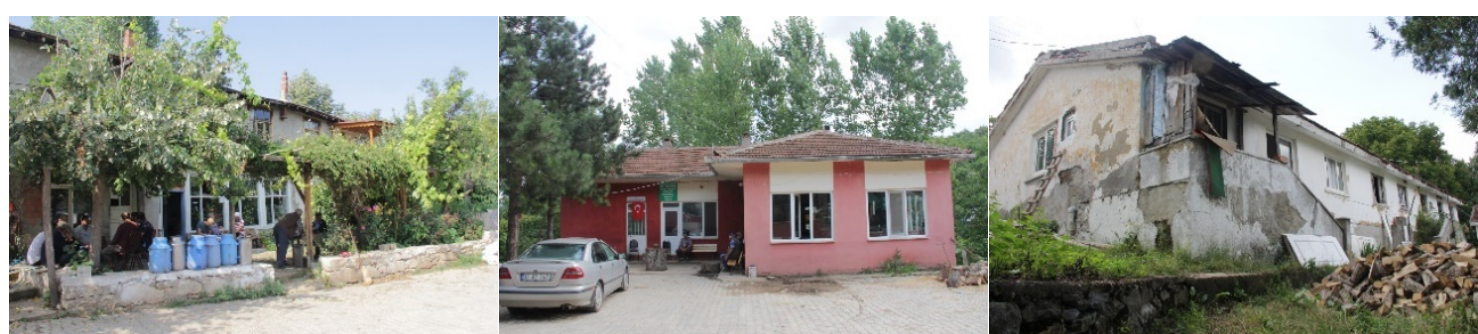

Şekil 6. Armutveren Muhtarık, Kahvehane, Okul yapıları, (Soner Yeler Arşivinden, 2018) 


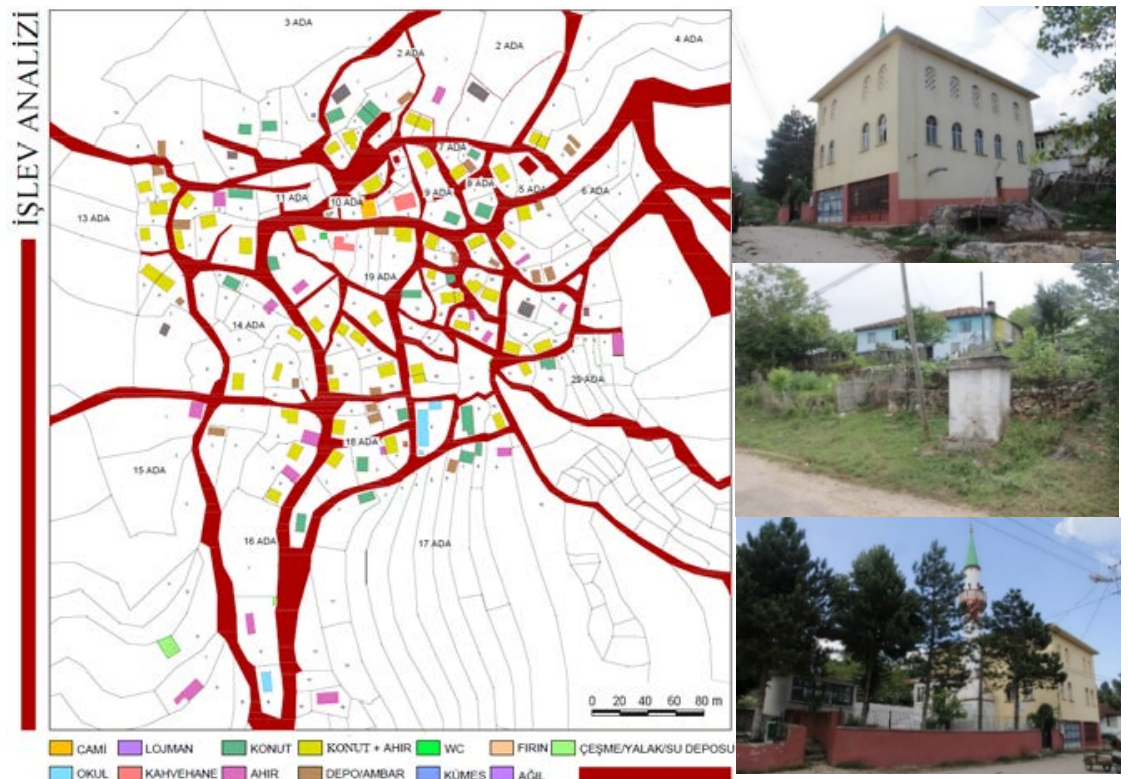

Şekil 7. Armutveren Köyü İşlev Analiz Paftası, (Soner Yeler Arşivinden, 2018)

\section{b. Kat Analizi}

Köyde yapılan alan çalışmasında, evlerin 60 adedinin (\%43) tek katlı olduğu tespit edilmiştir. Bu sayının içine ahır, ağıl ve samanlık gibi yüksek tek katlı yapılar da dâhildir. İki katlı 77 adet (\%57) olan konutların alt katları genellikle ahır veya depolama alanı olarak kullanılmaktadır.
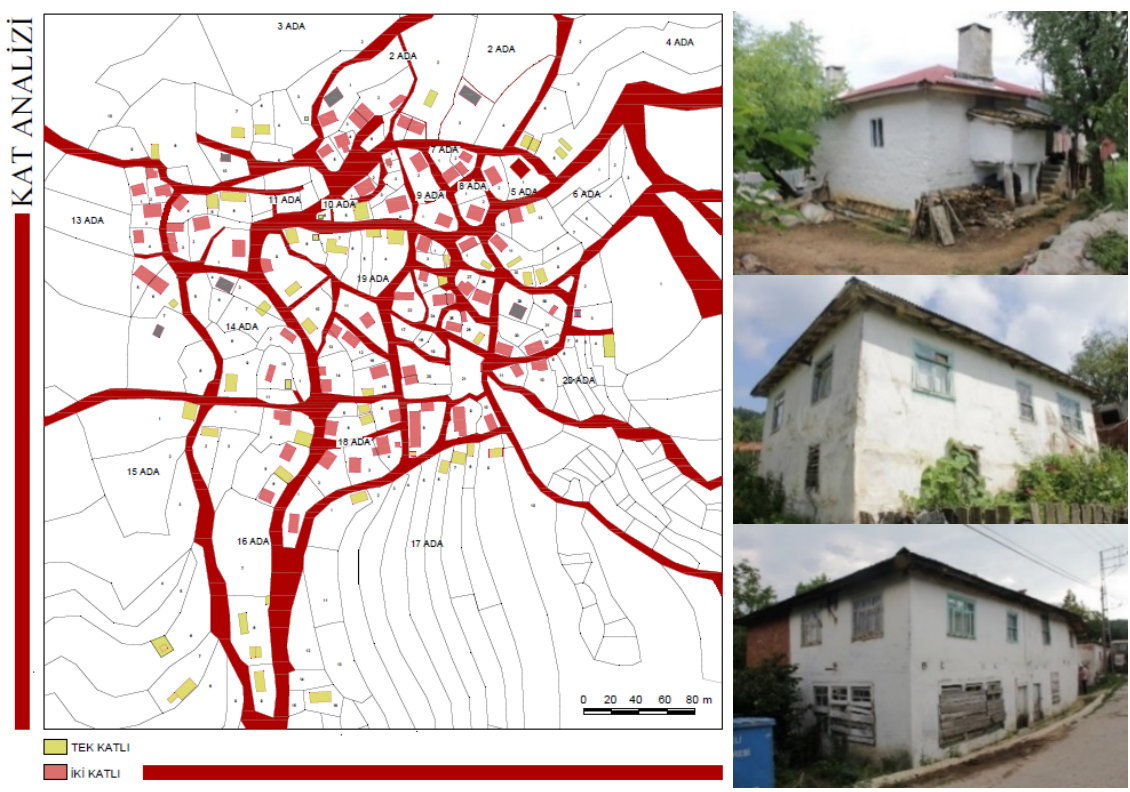

Şekil 8. Armutveren Köyü Kat Analiz Paftası, (Soner Yeler Arşivinden, 2018)

\section{c. Fiziksel Durum Analizi}

Yapıların genelinin yani 80 adedinin (\%58) fiziksel durumu kötüdür. Yapılan onarım ve yeni malzeme kullanımları ile binaların özgünlükleri kaybolmuştur. 12 adet (\%8) yapı ise harap durumdadır. Orta seviyedeki 40 adet (\%29) yapıda da onarımlar ve eksiklikler mevcuttur. İyi durumda bulunan yapı sayısı sadece 6 adet (\%4)'tir. 

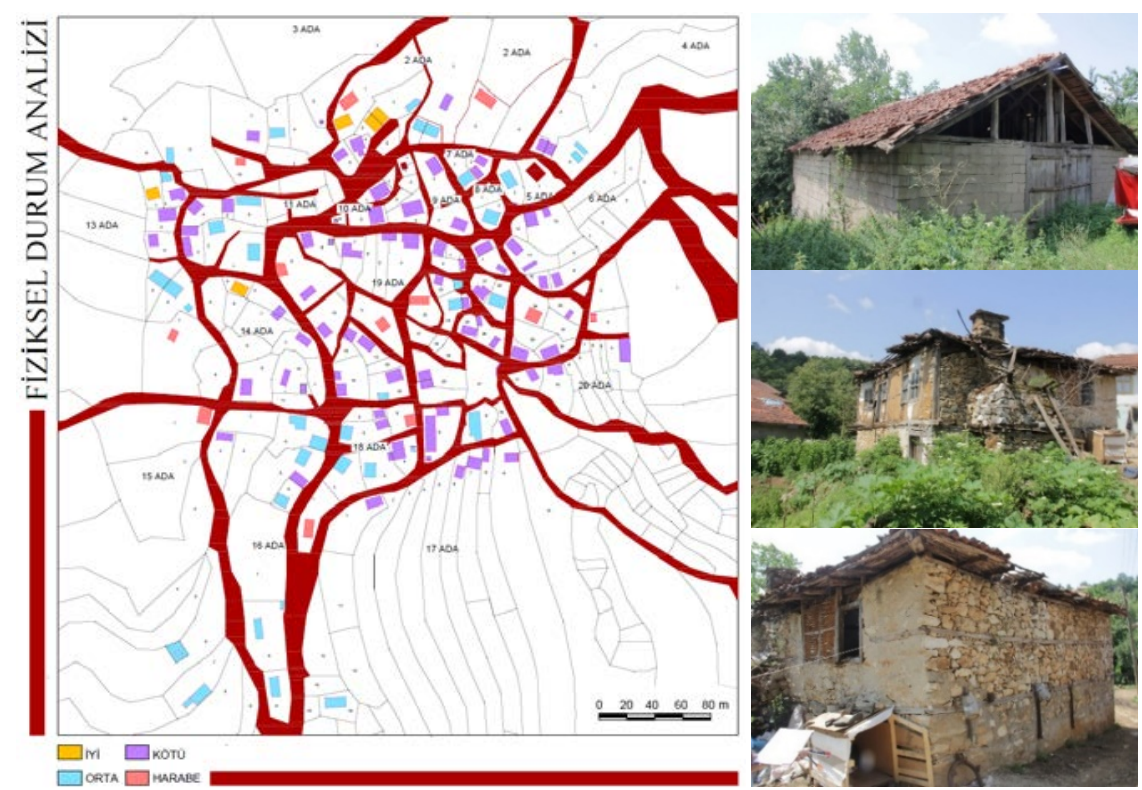

Şekil 9. Armutveren Köyü Fiziksel Durumu Analiz Paftası, (Soner Yeler Arşivinden, 2018)

\section{d. Yapım Tekniği Analizi}

Yapıların 56 adedi karma (\%40) ve 48 adedi de tuğla/briket (\%35) malzemeli yığma yapım sitemi ile inşa edilmiştir. Köy içeresinde sık sık bakımları yapılmış 11 adet yığma kerpiç (\%8) ve 2 adet yığma taş (\%1) yapı geleneksel kırsal mimari özelliklerini sürdürmektedir. Ayrıca 9 adet betonarme (\%8), 6 adet çakma ahşap (\%2) sisteminde yapı vardır. Yıkılmış yapıların sayısı 5'tir.
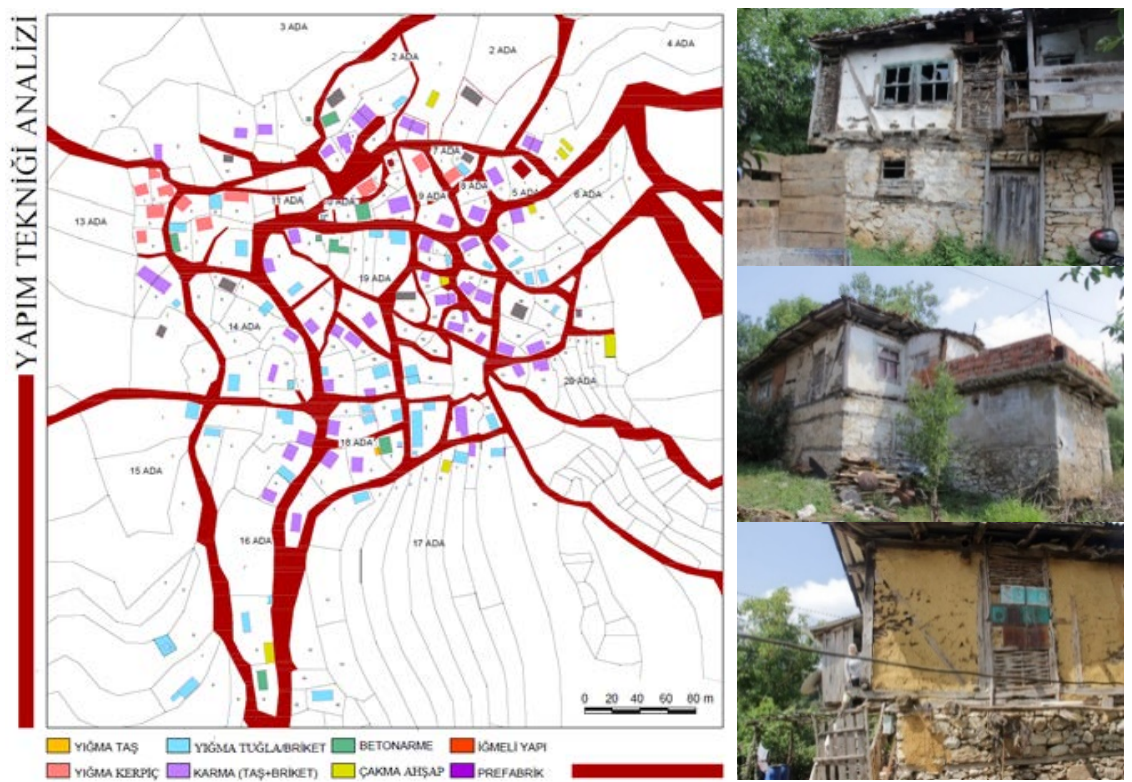

Şekil 10. Armutveren Köyü Yapım Tekniği Analiz Paftası, (Soner Yeler Arşivinden, 2018)

\section{e. Özgünlük Durumu Analizi}

Kırsal yapım tekniklerine ve çevre koşullarına göre kullanılan malzemeler göz önünde bulundurulduğunda, yapıların ancak 32 adedi (\%23) iyi seviyede özgünlüklerini korumuştur. Yapılan onarım ve bakımların fazla olduğu 19 adet (\%13) yapı orta seviye, 93 adet (\%67) yapı ise kötü olarak tespit edilmiştir. 

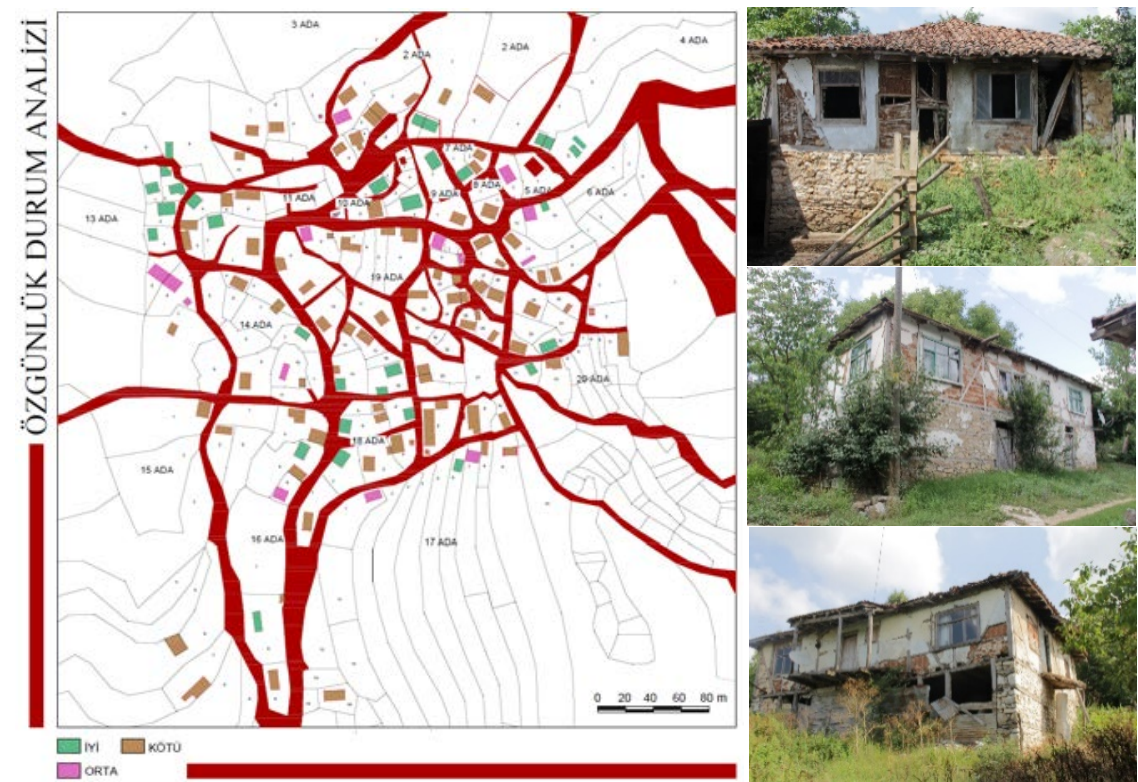

Şekil 11. Armutveren Köyü Özgünlük Durumu Analiz Paftası, (Soner Yeler Arşivinden, 2018)

\section{f. Örnek 1 Konut Analizi}

Seçilen 1. örnek, köyün güney batısında, 18 ada 2 parselde yer alan iki katlı konut+ahır kullanımlı bir yapıdır. Dikdörtgen biçimlenişli konutun zemin katında ahır, depo ve odunluk bulunmaktadır. Bahçeden rampa ile ulaşılan zemin subasman yüksekliği 50 cm'dir. İki kat da aynı boyuttadır. Alt kat ahır girişi ile konut üst kat girişi, kuzeydoğu yönündedir. Üst kata bağlantı, dışarıdan düz kollu bir merdivenle sağlanmaktadır. Konut, orta sofalı plan tipindedir. Odalar kareye yakın biçimde olup mekân boyutları birbirine yakındır. Plana sonradan eklenen bir banyo vardır. Alt ve üst katı birbirine bağlayan ve sofaya çıkan düz kollu merdiven, zaman içinde kullanım zorluğu nedeniyle kapatılmıştır. Yapının dış duvarları $60 \mathrm{~cm}$ kalınlığında ve yığma taş yapı sisteminde, iç duvarları 10-15 cm kalınlığında ve dolgulu ahşap karkas sistemindedir. Dış mekândan konut girişine kadar olan yükseklik $270 \mathrm{~cm}$ iken, alt kat iç mekân yüksekliği 250, üst kat iç mekân yüksekliği $231 \mathrm{~cm}$ 'dir. Çatı ve pencerelerde yapılan yenilemelerle yapının özgünlük durumu olumsuz yönde etkilenmiştir.

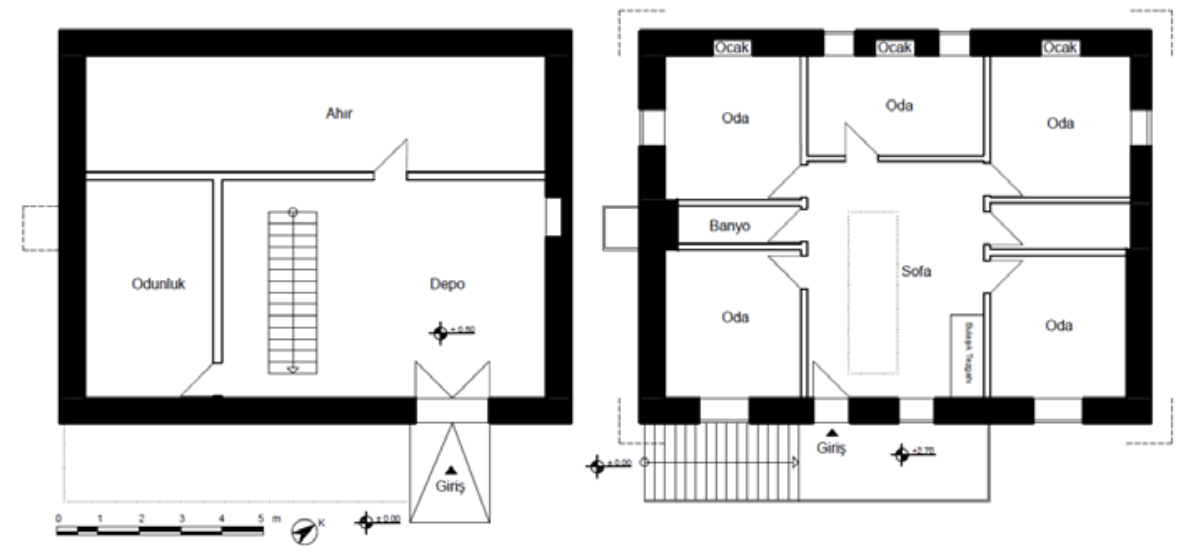

Şekil 12. Armutveren Köyü 18 ada 2 parsel konut alt katve üst kat planları, (Soner Yeler Arşivinden, 2018) 


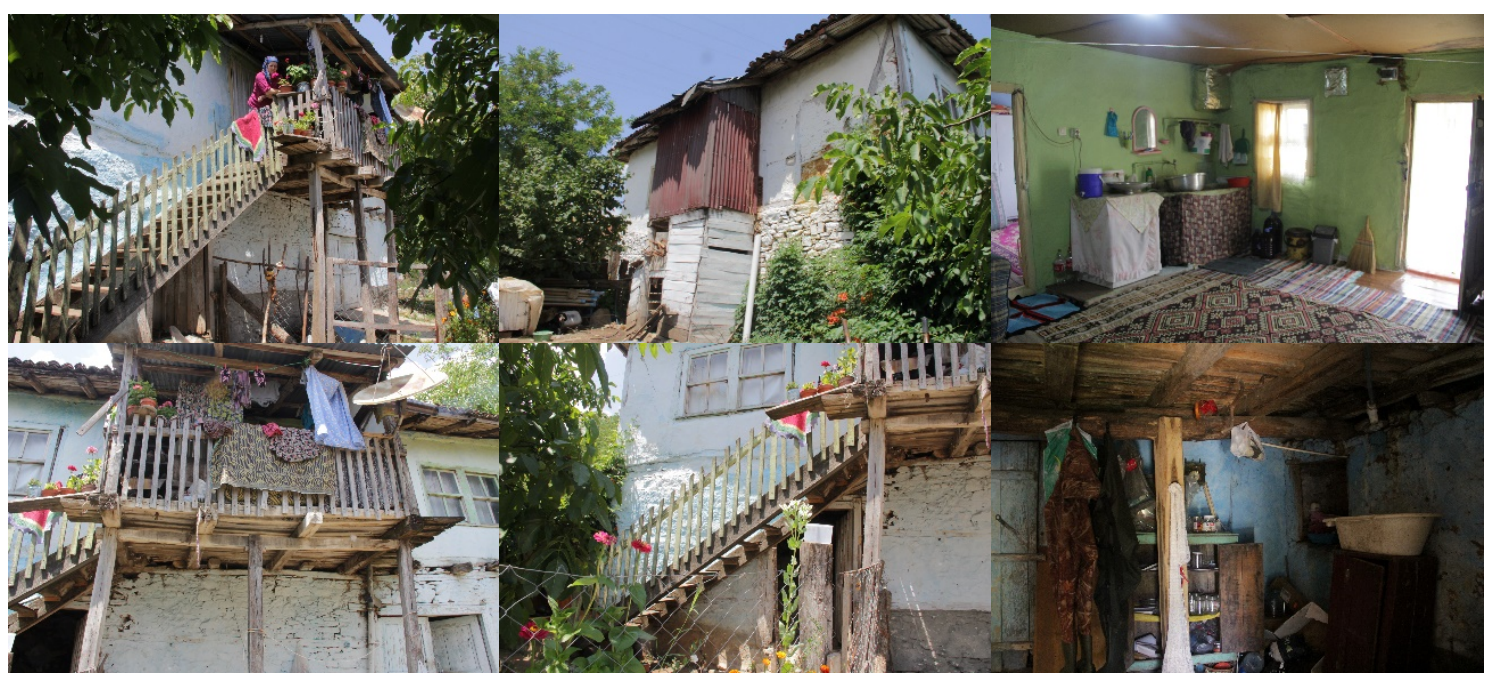

Şekil 13. Armutveren Köyü 18 ada 2 parsel konut iç ve dış görüntüleri, (Soner Yeler Arşivinden, 2018)

\section{g. Örnek 2 Konut Analizi}

Seçilen 2. örnek, köyün güney batısında, 2 ada 5 parselde yer alan iki katlı konut+ahır kullanımlı bir yapıdır. Dikdörtgen biçimlenişli konutun zemin katı eskiden ahır olarak kullanılırken günümüzde depoya dönüştürülmüştür. Bahçeden merdiven ile ulaşılan zemin katın subasman yüksekliği $50 \mathrm{~cm}$ 'dir. Üst kat, alt kattan giriş cephesi yönünde çıkmalı olarak düzenlenmiştir. Kuzeydoğu yönünde yer alan odada yapılan $150 \mathrm{~cm}$ 'lik çıkma ise sonradan yapılmış ve duvarı tuğla ile örülmüştür. Çıkma, çökmesin diye ahşap dikmelerle de desteklenmiştir. Alt kat girişi ile konut üst kat girişi, kuzeydoğu yönündedir. Üst kata bağlantı, dışarıdan düz kollu bir merdivenle sağlanmaktadır. Konut, orta sofalı plan tipindedir. Odaların biçimlenişleri ve boyutları birbirinden farklıdır. Yapının dış duvarları alt katta $80 \mathrm{~cm}$, üst katta $60 \mathrm{~cm}$ kalınlığındadır ve yığma taş yapı sistemindedir. İç duvarları $10-15 \mathrm{~cm}$ kalınlığında ve dolgulu ahşap karkas sistemindedir. Dış mekândan konut girişine kadar olan yükseklik $250 \mathrm{~cm}$ iken, alt kat iç mekân yüksekliği 217, üst kat iç mekân yüksekliği 193 cm'dir. Çatı ve pencerelerde yapılan yenilemelerle yapının özgünlük durumu olumsuz yönde etkilenmiştir.
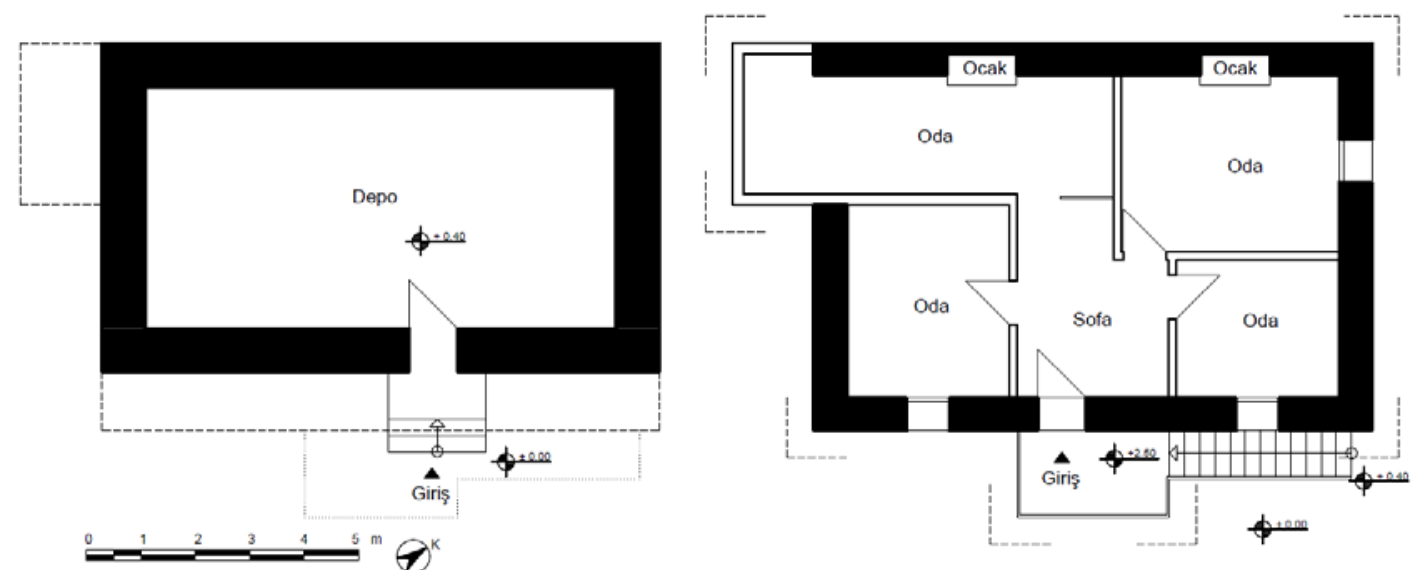

Şekil 14. Armutveren Köyü 2 ada 5 parsel konut alt kat ve üst kat planları, (Soner Yeler Arşivinden, 2018) 


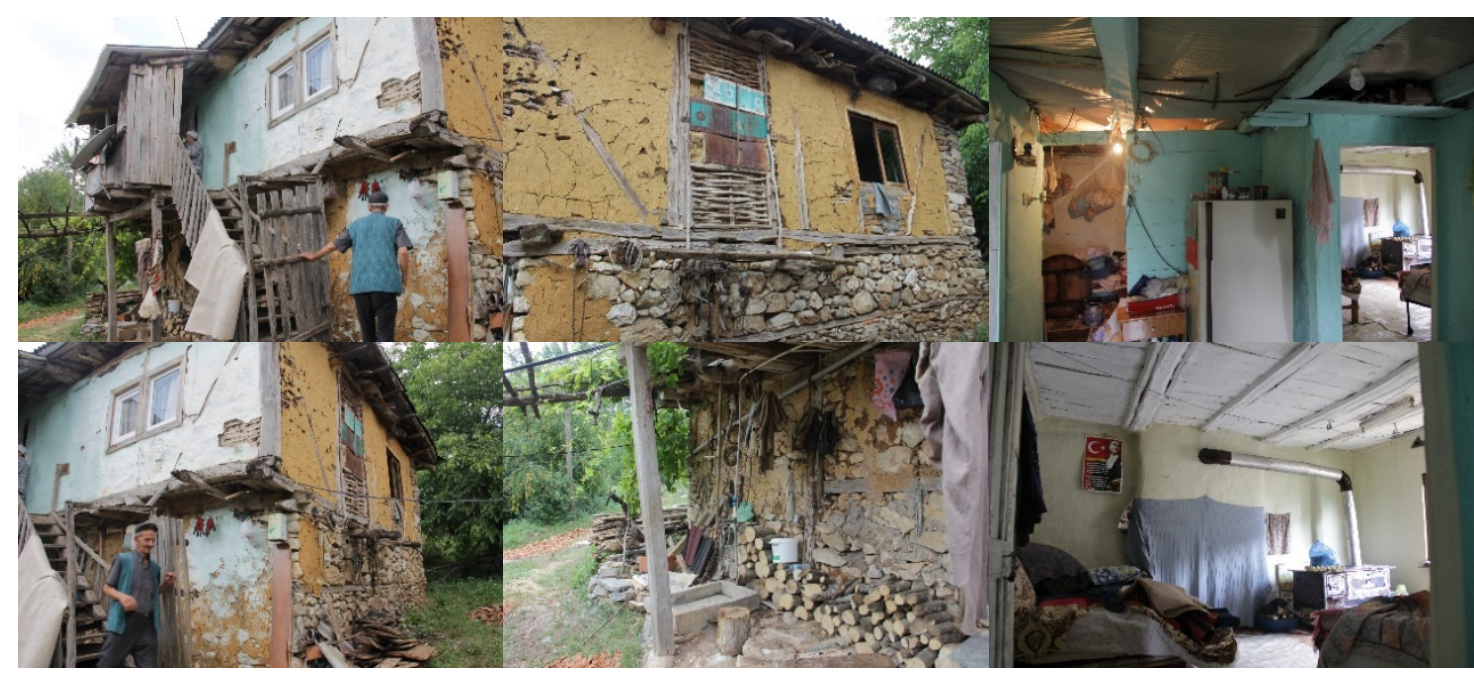

Şekil 15. Armutveren Köyü 2 ada 5 parsel konut iç ve dış görüntüleri, (Soner Yeler Arşivinden, 2018)

\section{Sonuç}

Armutveren Köyünde iklim yapısı, arazinin topografik yapısındaki çeşitlilik, bölgelere göre farklılık gösteren yapı taşı/malzemesi olarak kullanılabilecek zengin doğal kaynakların varlığı ve bölgede yaşayan halkın kültürel zenginliği nedeni ile konut tiplerinde de büyük bir zenginlik görülmektedir. Köyün toplu yerleşim karakterini bozmamak koşuluyla, her yöne doğru yeni yerleşim alanları oluşturulabilir. Köyün geçmişinde nüfusunun yüksek olması bu konut potansiyelini de göstermektedir.

Köyün mevcut parsel boyutları ve biçimleri için belirli bir tipoloji yoktur. Yeni yerleşim dokusunda planlama yapılırken, bu alanların kullanımında doğal kaynakları, verimli toprak yapısını ve yasa/yönetmeliklere de dikkat edilerek yeni düzenlemelere izin verilmelidir (Çorapçıoğlu, vd., 2011, s.318).

Köyün genel yapısında bakımsız kalan ve kullanılmayan özgün yapıların bozulduğu, yeni yapılarda betonarme yapım sistemlerin olduğu ve bu yapıların yükseklerinde farklııklar ortaya çıktığı görülmektedir. Bu kapsamda, geleneksel yapım malzeme ve tekniklerinin sürdürülmesi (Aran, 2000, s.14-15) ile geleneksel dokunun bozulmasına engel olunabilir. Köyün ormanlık bölgede yer alması, bunu gerçekleştirebilme olasıllığını ortaya koymaktadır.

Köyün ev plan tiplerinde bakıldığında, kullanıcıların hayvancılık ve tarım faaliyetlerine dayanan yaşam biçiminin, konutların alt katlarının ahır veya depo olarak üst katlarının da yaşam alanı olarak kullanılmasında etken olmuştur. Yukarıda bahsi geçen özgün köy ev planları Eldem'in (1954, s. 127-128) geleneksel ev tipolojilerinden eyvanlı orta sofa plan tipiyle örtüşmektedir.

Orta sofalı plan tipine sahip olan yapıların en belirgin özellikleri, kare veya dikdörtgen planlı olması ve sofanın ise pahlı veya oval şeklinde olmasıdır. Bu plan tipinin tasarımında odalar yapının her köşesine yerleştirilmiştir. Odaların arasında da servis mekanları olan merdiven, eyvan, kiler, mutfak, hale gibi alanlar yer verilmiştir. Sofa ilk zamanlar keskin hatlara sahip dört köşeden meydana gelirken daha sonra sofanın köşe kısımlarında pahlar kırılarak oval şekle dönüştürülmüştür. Bunun sonucunda da ortak mekan olan sofa daha güvenli bir hal alırken evin ısınmasında da önemli rol 
oynamıştır. Odalar arasındaki uzaklığın azaltımasıyla mekânsal organizasyondaki daha bütüncül bir plan tipi ortaya çıkmıştır (Eldem, 1954, s. 127-128).

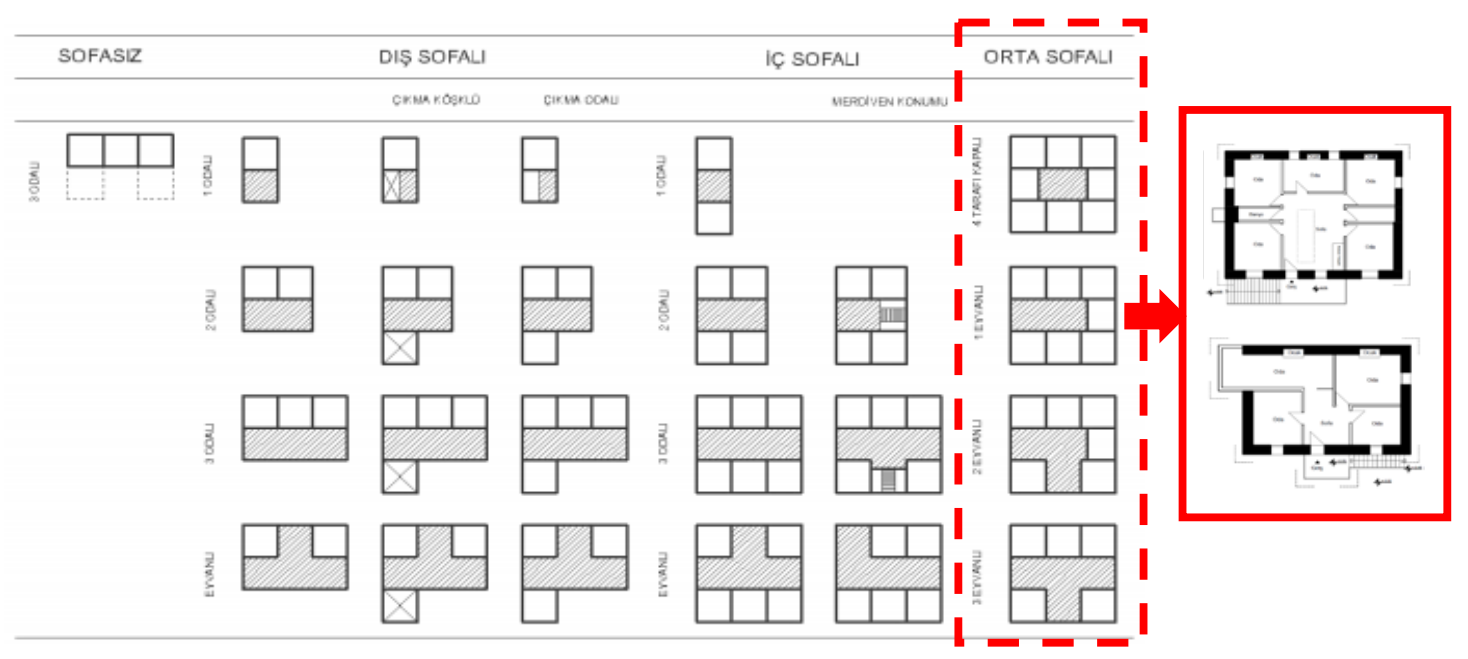

Şekil 16. Çalışma kapsamında incelenen evlerin, Sedad Hakkı Eldem'in Türk evi tipolojisi ile ilişkilendirilmesi (Eldem (1972, s. 180-182)' den düzenlenmiştir).

Şekil 16'da görüldüğü gibi, Sedad Hakkı Eldem orta sofalı plan tiplerini de kendi içinde 4 'de ayırarak sınıflandırmıştır. Çalışmada incelenen evlerin sınıflandırmada okla belirtildiği gibi "1 eyvanlı orta sofalı" plan tipine yakın ve dikdörtgen planlı olduğu görülmektedir. Odalar da benzer şekilde sofanın etrafında sıralanmıştır. Ancak, pahlı veya oval sofalara bu örneklerde rastlanılmamıştır. Türk evi tipolojisinde gösterilen eyvan ise örnek ev planlarında, merdiven ve mutfak gibi servis mekanlarına dönüşmüştür. Köyün genelinde yeni yapı uygulamalarında bu tipolojinin korunması, hem yerleşim dokusunun korunmasına hem de iç mekân kurgusunun sürdürülmesine katkı sağlayacaktır. Bu yönüyle üretime yönelik faaliyetlerinde artacağından, özellikle göç eden köydeki genç nüfusa alternatif iş olanakları yaratılarak göçün engellenmesi sağlanacaktır.

Yerleşim içinde, ana yolların yerel kimliğe uygun doğal yapı malzemelerinden seçilmesi, ara yollar ve dar geçitler vb. yolların doğal yapısında bırakılması tercih edilmelidir (Görgün ve Yörür, 2018, s. 25-47).

Sonuçta köyde yaşam kalitesinin artırılması ve kırsal yaşam özelliklerinin sürdürülebilirliği için dile getirilen önerilerin uygulanması öncelikli olarak ele alınmalıdır. Birçok illerde farklı şekilde uygulanması daha doğru olabilir. Genel olarak köyler ile ilgili çözüm üretme sürecinde; günün yaşam koşullarına uygun, köyleri mevcut olan kimlikleri ile değerli kılacak, uygulanabilir ve örnek teşkil edecek düzenlemeler geliştirmektir. 


\section{Kaynaklar}

Aran, Kemal, Barınaktan Öte: Anadolu Kır Yapıları, Tepe Mimarlık Kültürü Merkezi, 2000, s.14-15.

Bursa Büyükşehir Belediyesi, Tarihi Kentler Birliği ve ÇEKÜL Vakfı, "Anadolu'da Kırsal Mimarlık", 2012, s. 5-24.

Cambaz, E., Demirköy Samakocuk'ta Osmanlı Dönemi Demir Dökümhanesi Mescidi Restorasyon Projesi, Yüksek Lisans Tezi, İstanbul Teknik Üniversitesi Fen Bilimleri Enstitüsü, İstanbul, 2007, s.10-14.

Çorapçıŏlu, K. vd., "Balıkesir Kırsalında Yöresel Doku ve Mimari Özelliklere Uygun Yapılaşmanın Yaygınlaştırııması", T.C. Bayındırlık ve İskân Bakanlığı Teknik Araştırma ve Uygulama Genel Müdürlüğü, Stratejik Planlama ve Kırsal Alanlar Daire Başkanlığı, İstanbul, 2011, s. 318.

Çorapçıŏlu, K. vd.," Kayseri Kırsal Alanında Yöresel Mimari Özelliklerin Belirlenmesi", T.C. Bayındırlık ve İskan Bakanlığı Teknik Araştırma ve Uygulama Genel Müdürlüğü, MSGSÜ Döner Sermaye İşletmesi Müdürlüğü, İstanbul, 2008, s. 1-3.

Eldem, S. H., Türk Evi Plan Tipleri, İstanbul Teknik Üniversitesi, İstanbul, 1954, s. 127128

Eldem, S. H., Türk Evi Plan Tipleri, İstanbul Teknik Üniversitesi, Mimarlık Fakültesi Yayınları, İstanbul , 1972, s.180-182.

Eminağaoğlu, Z., "Kırsal Yerleşmelere İlişkin Tasarım ve Planlama Politikalarının Bölgesel Ölçek İçinde Değerlendirilmesi”, Planlama Dergisi, Sayı:32, İstanbul 2005, s.72-81.

Eminağaoğlu, Z., Çevik, S., "Kırsal Yerleşmelere İlişkin Tasarım Politikaları ve Araçlar", Gazi Üniversitesi Mühendislik-Mimarlık Fakültesi Dergisi, Cilt:22, No:1, Ankara 2007, s.157-162.

Görgün, K. E. ve Yörür, N., Kırsal yerleşmelerde özgün dokunun korunmasında bir araç olarak köy tasarım rehberleri: Ödemiş bademli örneği, TÜBA-KED, Sayı-17, Ankara 2018, s. 25-47.

Kırklareli Belediyesi, Kırklareli İ Yılığı, Kırklareli, 1967

Kırklareli Belediyesi, Kırklareli İı Yıllığı, Kırklareli, 1972

Kırklareli Belediyesi, Kırklareli İI Yıllığı, Kırklareli, 1990

Korkut, A., Serhat Şehri Kırklareli, Dizerkonca Matbaası, İstanbul,1960

Küçükoğul, S., Türkoğlu, H., Kırsal Yerleşmelerde Yaşam Kalitesinin Ölçülmesi için Bir Yöntem Önerisi: Bursa Köylerinden Örnekler, Planlama; Sayı 31(1), 2021, s. 47-62 I doi: 10.14744/planlama.2020.93685

Özdoğan, H., Kırklareli Ili Köy Adları Incelemesi, Yüksek Lisans Tezi, Kırklareli Üniversitesi Sosyal Bilimler Enstitüsü, Kırklareli, 2016, s.42-43. 
Yürekli, K. Ferhan, "Çevre Görsel Değerlendirmesine İlişkin Bir Yöntem Araştırması", İstanbul Teknik Üniversitesi, İstanbul, 1977.

\section{İnternet Kaynakları}

URL-1, https://www.lafsozluk.com/2009/04/demirkoy-nerededir-nereye-baglidir.html (E.T.:16.06.2021)

URL-2, $\quad$ https://www.uyduharita.org/kirklareli-haritasi-resimleri/kirklareli-haritasi3/(E.T.:16.06.2021)

URL-3, http://www.trakyagezi.com/paspala-fasulyesi/(E.T.:16.06.2021)

URL-4, http://www.nufusune.com/19549-kirklareli-demirkoy-armutveren-koy-nufusu (E.T.:16.06.2021) 